\title{
"Assessing the relationship between non-cash payments and various economic
}

indicators"

\begin{tabular}{|c|c|}
\hline AUTHORS & $\begin{array}{l}\text { Anna Kredina (i) } \\
\text { Saule Nurymova (i) } \\
\text { Azimkhan Satybaldin (i) } \\
\text { Anel Kireyeva (i) } \\
\text { R }\end{array}$ \\
\hline ARTICLE INFO & $\begin{array}{l}\text { Anna Kredina, Saule Nurymova, Azimkhan Satybaldin and Anel Kireyeva (2022). } \\
\text { Assessing the relationship between non-cash payments and various economic } \\
\text { indicators. Banks and Bank Systems, 17(1),67-79. } \\
\text { doi:10.21511/bbs.17(1).2022.06 }\end{array}$ \\
\hline DOI & http://dx.doi.org/10.21511/bbs.17(1).2022.06 \\
\hline RELEASED ON & Thursday, 10 February 2022 \\
\hline RECEIVED ON & Wednesday, 22 December 2021 \\
\hline ACCEPTED ON & Wednesday, 26 January 2022 \\
\hline LICENSE & $\begin{array}{l}(c) E Y \\
\text { This work is licensed under a Creative Commons Attribution } 4.0 \text { International } \\
\text { License }\end{array}$ \\
\hline JOURNAL & "Banks and Bank Systems" \\
\hline ISSN PRINT & $1816-7403$ \\
\hline ISSN ONLINE & $1991-7074$ \\
\hline PUBLISHER & LLC "Consulting Publishing Company "Business Perspectives" \\
\hline FOUNDER & LLC "Consulting Publishing Company "Business Perspectives" \\
\hline
\end{tabular}

NUMBER OF REFERENCES

36

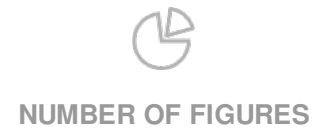

2
NUMBER OF TABLES

5

(C) The author(s) 2022. This publication is an open access article. 


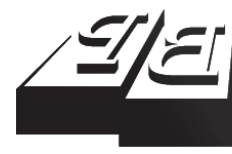

\section{BUSINESS PERSPECTIVES}

LLC "CPC "Business Perspectives" Hryhorii Skovoroda lane, 10, Sumy, 40022, Ukraine www.businessperspectives.org

Received on: $22^{\text {nd }}$ of December, 2021 Accepted on: $26^{\text {th }}$ of January, 2022 Published on: $10^{\text {th }}$ of February, 2022

(C) Anna Kredina, Saule Nurymova, Azimkhan Satybaldin, Anel Kireyeva, 2022

Anna Kredina, Ph.D. Candidate, Finance and Accounting Department, University of International Business, Kazakhstan.

Saule Nurymova, Ph.D. Candidate, Economics Department, Al-Farabi Kazakh National University, Kazakhstan.

Azimkhan Satybaldin, Professor, Doctor of Economics, General Director, Institute of Economics MES RK, Kazakhstan.

Anel Kireyeva, Ph.D. in Economics Institute of Economics MES RK, University of International Business, Kazakhstan. (Corresponding author)

This is an Open Access article, distributed under the terms of the Creative Commons Attribution 4.0 International license, which permits unrestricted re-use, distribution, and reproduction in any medium, provided the original work is properly cited.

Conflict of interest statement: Author(s) reported no conflict of interest

Anna Kredina (Kazakhstan), Saule Nurymova (Kazakhstan),

Azimkhan Satybaldin (Kazakhstan), Anel Kireyeva (Kazakhstan)

\title{
ASSESSING THE RELATIONSHIP BETWEEN NON-CASH PAYMENTS AND VARIOUS ECONOMIC INDICATORS
}

\begin{abstract}
This study is aimed at evaluating the correlation between determinants of non-cash payments (ATMs, number of bank branches, and number of mobile phone users) and various economic indicators (broad money, inflation, consumer prices) as well as further studying which of the factors and to what extent influence each other in different periods. Non-cash payments are provided by ATMs. The sample considers panel data on nine developing countries. The data for calculation were taken from The World Bank, for Kazakhstan - from the Bureau of National Statistics of the Republic of Kazakhstan. The data collected during the study were analyzed using the SPSS software. Spearman's correlation analysis was used. The results obtained in the empirical study briefly showed that the alternative hypothesis is confirmed for the period 2004-2009 (that the existing relationships are significant), at the same time, the null hypothesis was confirmed in terms of the level of significance for the period 2019-2020. Accordingly, this study showed that modern developments differ from those provided earlier and financial technology transformation is still in the process. The results of this study also indicated the need for further studies of non-traditional measures of financial development, which can lead to sustainable economic growth in the post-crisis period.
\end{abstract}

\section{Keywords}

JEL Classification

\section{INTRODUCTION}

At present, the consequences of the crisis caused by the COVID-19 pandemic are great. States are solving economic problems with proven methods. They mainly use state programs that were applied after the 2008 crisis. At that time, government money was injected into the banking system to revive the economy that had suffered from non-repayable loans. In the following years, a new round appears and technologies merge with financial services, creating new banking products. Creation and fast development of the financial technologies sector for non-cash payments occurred.

Banking, non-cash payments, online trading via mobile phones, and other factors are mainly studied (Mahran \& Enaba, 2011; Riedl et al., 2015; Yu et al., 2019). However, in the beginning, there were problems of integration between technologies in different countries that were solved through platformization. Apple, Google, Samsung, PayPal, eBay, AliExpress, Amazon, etc., improved significantly. Moreover, with the help of these and other platforms, e-commerce of food, delivery, taxi, and other related areas flourished (De et al., 2020; Gawer, 2014). Most of the studies consider the impact of the pandemic on the economy of a country or individual economic sectors (Sreelakshm \& Prathap, 2020; Ren \& Tang, 2020). 
There are debates among scientists about the impact of the number of bank branches and a country's GDP. Some regard that many banks are positive for economic processes (Kumbirai \& Webb, 2010; Aysan \& Ceyhan, 2008). Others are in favor of reducing the number of banks, since online banking currently provides similar services more efficiently (Spokeviciute et al., 2019). Additionally, it is even safer to use ATMs, especially since recently this equipment has been equipped with multi-factor personal identification systems (Islam et al., 2007; Luca et al., 2010).

The recent COVID-19 pandemic made the banking sector rethink how to provide banking, which is why many countries are now required to comply with social distancing measures. Whereas current crisis is different from the previous one in the focus of the impact: development and or vice versa degradation, which may affect the closure of some sectors of the economy. The pandemic has become a trigger of the development of non-cash transfer technologies. The main instrument for transfer between cash and non-cash money is ATMs. Other determinants such as the number of bank branches, the number of mobile phone users, broad money, and inflation were also studied. Therefore, in this study, an attempt was made to investigate the factors that will determine the level of penetration of banking services and financial technologies in different periods.

\section{LITERATURE REVIEW}

Non-cash payments are an additional means of protection and minimize contact through cash in the context of the COVID-19 pandemic. According to $\mathrm{WHO}$, as of 2020 , the virus affected more than 200 countries, while more than 20 million people were infected with the virus, wherein WHO is waiting for the disease to further spread (WHO, 2020). Such a number supports that a greater part of the population will relatively soon switch to the use of non-cash payments only. At the same time, mobile services are the ways for social distancing (Sreelakshm \& Prathap, 2020; Ren \& Tang, 2020).

In the academic literature, there are various studies that explore internet payments, online payments, and mobile payments from different perspectives. Certainly, this called for electronic money. The development of the non-cash payment sector manifests in the growth of electronic commerce, trade. Scientists investigate and develop new software systems on the interaction between clients and a business, while banks repeat top-performing projects after the leaders - Kaspi.kz (Soldatenko \& Essimzhanova, 2021). Some considered mobile payments become more widespread due to the interaction between sellers, buyers, banks, and the government (Mahran \& Enaba, 2011; Riedl et al., 2015; Yu et al., 2019). Others considered that electronic commerce in the very beginning developed through computers by using online banking, which allowed en- tering a card number to carry out a transaction. Other researchers regarded that e-commerce at the very beginning flourished through computers through the use of online banking, which made it possible to enter a card number to complete a transaction (Dahlberg et al., 2008; Chen \& Nath, 2008). However, some researchers studied not only perspectives but also problems that appeared as a result of online sales development in the digital context (Casado-Aranda et al., 2018). Even though in 2008 mobile payments were in their infancy, it required a few years for large-scale development that the population of many countries now uses these technologies.

The growth of mobile phone users made companies create software that supports online payment directly from the phone. This has resulted in bank branches' competitiveness declining over time compared to non-bank payment systems. Bank branches began to decline in several countries, although scientists have proven a positive effect on a country's real GDP from the development of the banking system and, in particular, from the number of bank branches in rural areas (Kumbirai \& Webb, 2010; Aysan \& Ceyhan, 2008). Interestingly, recently some scientists have another point of view that developed countries, on the contrary, concluded that the closure of inefficient banks has a positive effect on the economy (Spokeviciute et al., 2019).

ATMs began to perform some functions of cash registers for paying utility bills or transferring 
funds to another country. Currently, the most recent achievements are the issuance of plastic cards, which previously took up to several weeks (Afaha, 2019; Luca et al., 2010). It should also be noted that the number of ATM fraud increased, accordingly, multifactorial identification, as a way to reduce the risk of using someone else's card, brought a positive effect of protecting the client's funds when withdrawing cash (Kaur et al., 2019; Islam et al., 2007). Generally, the development of ATMs was considered by various scientists with a technical component, after all, the first ATMs had complex codes, took up a lot of space, and performed only the function of issuing cash. For instance, Joseph and Stone (2003) developed a grid for bank managers when making decisions regarding the priority of implementing service-oriented technology. Gradually Al-Hawari et al. (2005) offered a model of the quality of banking services, taking into account the unique characteristics of various delivery channels, including ATM, online banking, and other aspects. Thus, ATM manufacturers understood that online trade anticipated the ATM manufacturing industry. There occurred a risk of refusal from the technologies by banks, therefore scientists started to actively look for ways of introducing the multifunctionality of this technology.

As a result, the COVID-19 pandemic has been the accelerator of the sharp distribution of noncash payments and non-cash payoffs. Distance payment has become a popular tool, especially in countries with low card usage. These relate to both developed and developing countries, for example, of all banks in Kazakhstan, the most high-tech one for 2020 is Kaspi. It was this bank that first introduced this payment method in 2017. It should also be noted that ATMs like Kaspi are high-tech: you can get a personalized plastic card in a few minutes. Certainly, such a payment technology is tied to the Internet. At this point, modern problems associated with internet fraud occur. Protection of the personal data of clients by most banks is provided through encoding and storing transaction data in reliable servers. Transactions are carried out in payment systems using QR codes, this is the latest achievement at the moment (De et al., 2020; Alamoudi, 2022).
Ebrill and Fries (1991) provided empirical studies for the identification of key factors influencing the existence of the relationship between inflation and the demand of the population for broad money. Further, Kumbhar (2011) identified factors that affect services of the ATMs provided by banks of public and private sectors. Factor analysis results showed that safety and efficiency of ATM servicing are the most important factors affecting customer satisfaction. Next, the study by Cobham and Kang (2012) is interesting because it proved the impact of Broad Money on the flow of finance in any of the country's financial links: derivatives, stocks and bonds, government securities, and savings of the population (which are not visible, since they are not in active circulation). The research results confirmed the direct positive impact of Broad Money on real GDP. Although the study included only the crisis years of 2008-2009 based on an analysis of the developed economy using the example of Great Britain.

The COVID-19 pandemic has also affected the level of inflation, slowing business relation, and the drop in production in developing countries has led to an increase in the level of inflationary risks (Banerjee et al., 2020). In this study, there is a predicted analysis of correlations, particularly conditioned to the latest crisis phenomena caused by the COVID-19 epidemic based on panel data for developing countries. The inflation rate indicator evokes a lot of controversy among scientists. Thus, the introduction of technologies and digitalization of the main economic processes did not particularly affect inflation (Ball \& Sheridan, 2004). While in countries with developing economies money, credit policy was tied to target inflation, which showed excellent economic growth indicators, although 36 developing countries were considered (Gonçalves \& Salles, 2008). Such studies excluded countries like Kazakhstan, Ukraine, Kyrgyzstan, and others. Therefore, the aim of this study is to analyze the impact of the pandemic on the financial technologies sector. Due to this, five indicators were studied, among which ATMs acted as a proxy server for non-cash payments. Thus, the aim of this study is to analyze the factors (other determinants) affecting the level of banking services and financial technologies elaboration in various countries before and after COVID-19. 


\section{AIMS AND HYPOTHESES}

The aim of this study is to evaluate correlations between determinants of non-cash payments and various economic indicators (broad money, inflation, consumer prices) and identify which of the factors and to what extent influence each other in different periods. The study puts forward the following hypotheses:

H0: The correlation coefficient is zero, i.e., there is no relationship between ATMs and independent indicators (including economic indicators).

H1: The correlation coefficient is not zero, i.e., there is a relationship between ATMs and independent indicators (including economic indicators).

\section{RESEARCH METHODS}

There are several studies that have explored the impact of the crisis in 2008 and the COVID-19 pandemic on the financial system. The correlation coefficients are calculated to identify the relationship between the variables. To provide the calculations, software programs such as Stata, SAS, SPSS are used. Although some scientists conducted a regression analysis to study the chosen indicators (Ebrill \& Fries, 1991; Cobham \& Kang, 2012), in this work correlational analysis will be applied. The Pearson and Spearman rank correlation coefficients are applied depending on the normality of the data distribution (Nettleton, 2014; Shkolnyk et al., 2019; Oliveira et al., 2020;). These software programs also allow checking the data for normal distribution. In this study, graphical method and plotted quantiles, or the so-called Q-Q plots (Quantile-Quantile plots), will be applied. In general, in various scientific studies, it is customary to use the formula for calculating the Spearman's correlation coefficient, which is calculated using the formula below (1):

$$
r_{x y}=1-\frac{6 \Sigma d^{2}}{n\left(n^{2}-1\right)},
$$

where $d^{2}-$ sum of squared differences between ranks; $n$ - number of features in the ranking; $x$ independent variable; and $y$ - dependent variable.
To check the correctness of the matrix compilation based on the checksum calculation, additional calculations will be carried out. If the sum over the columns of the matrix is equal to each other and the checksum, then the matrix is composed correctly.

$$
\sum x_{i j}=\frac{(1+n) n}{2},
$$

where $i$ - the value of the first parameter; $j$ - the value of the $j$ parameter; and $n$ - number of features in the ranking.

After obtaining the totals of the ranks or calculus of the checksum, the metric ratios required for this study will be provided. Based on the obtained data, the indicators will be distributed from more significant to less significant. Moreover, variables were chosen on the basis of the expert opinion method based on their significance, which is used in this study. Table 1 shows the indicators used in the study.

Table 1. Variables and their measurements used in the study

\begin{tabular}{|c|c|c|c|}
\hline No. & Abbreviation & Description & $\begin{array}{c}\text { Unit } \\
\text { measurements }\end{array}$ \\
\hline \multicolumn{4}{|c|}{ Dependent indicators } \\
\hline 1 & ATM & $\begin{array}{l}\text { Automated teller } \\
\text { machines (ATMs) }\end{array}$ & $\begin{array}{c}\text { per } 100,000 \\
\text { adults }\end{array}$ \\
\hline \multicolumn{4}{|c|}{ Independent indicators } \\
\hline 2 & MCS & $\begin{array}{l}\text { Mobile cellular } \\
\text { subscriptions }\end{array}$ & per 100 people \\
\hline 3 & CBB & $\begin{array}{l}\text { Commercial bank } \\
\text { branches }\end{array}$ & $\begin{array}{l}\text { per } 100,000 \\
\text { adults }\end{array}$ \\
\hline 4 & BM & Broad Money & $\%$ of GDP \\
\hline 5 & $\operatorname{lnf}$ & $\begin{array}{l}\text { Inflation, consumer } \\
\text { prices }\end{array}$ & annual \% \\
\hline
\end{tabular}

Source: Compiled by the authors.

The suggested set of data was rather small as the sample did not include some indicators due to the limited available data. On the whole, the suggested methodology was developed considering limitations, and this is completely normal since it was necessary to minimize their range within the framework of this study. Therefore, in this study, the following algorithm of actions will be conducted:

First step: Collection and processing of quantitative data - data are given for 9 countries over 17 years, namely for 2004-2020. 
Second step: Analysis of the number of bank branches and ATMs in the countries under consideration.

Third step: Checking the data for normality (descriptive statistics and a graphical method were applied through the construction of P-Plots diagrams).

Fourth step: Calculation of the Spearman correlation coefficients for 2004, 2007, 2008, 2019, and 2020 and comparing the results.

To show the dynamics of changes in the degree of influence of the chosen indicators in the countries under consideration, a 5-year period was taken. Table 1 shows data for 2004 (the basic year was used for calculations), 2007, and 2009 as the years preceding the crisis years; 2008 and 2020 are the years of crises, the 2008 financial crisis and the 2020 crisis as a result of the COVID-19 pandemic.

\section{ANALYSIS}

This study used data for 2020 from the countries of the former Soviet Union, in particular Kazakhstan, Kyrgyzstan, Ukraine, Belarus, and Russia, as well as some EU countries such as-Czech Republic and Hungary, and developing countries like Romania and Serbia. Uzbekistan was supposed to be included as well in the research, but the lack of data did not allow including the country in this study.

In recent years, scientists studying non-cash payments, more often investigate ATMs, the number of which is still being increased in developing countries and decreased in developed countries. There are studies that show a positive relationship between the number of ATMs and a country's GDP (Islam et al., 2007). The ATM acts as an intermediary in areas where there are problems with wireless Internet. Of course, banks serving ATMs charge a commission for issuing cash to a client. Often, such commissions are charged only after exceeding the specified amount. The transfers themselves are conducted in electronic interbank clearing systems (Afaha, 2019). Furthermore, in some countries there are limits on cash withdrawals per day; in Kazakhstan, this limit is from 600 to 900 US dollars per day and it depends on the bank servicing the ATM.

In this study, panel data on the number of ATMs in the country per 100,000 adults were taken and given per capita, for comparison with Kazakhstan. The data on the number of ATMs in Serbia for 2020 were absent on the World Bank website, due to which the authors left the number of ATMs for 2019. The lack of data on the number of bank branches per 100 adults for 2020 in Serbia and Belarus was also supplemented by the authors based on the data of 2019: Serbia - 27.6, Belarus - 0.8. Population data were taken from the World Bank, for Kazakhstan - from the Bureau of National Statistics of the Republic of Kazakhstan. The results are shown in Table 2.

Based on the provided data for 2004-2020, it is clear that on average the number of ATMs increased several times in all countries. The highest indicators on the number of ATMs from 2004 are in Russia, Kazakhstan, and Ukraine. Such indicators are obvious because given countries from

Table 2. Dynamics of the count of ATMs (per 100,000 adults)

Source: Compiled by the authors based on data from the World Bank (2020).

\begin{tabular}{|c|c|c|c|c|c|c|c|c|c|c|c|c|c|c|c|c|c|}
\hline Country & 2004 & 2005 & 2006 & 2007 & 2008 & 2009 & 2010 & 2011 & 2012 & 2013 & 2014 & 2015 & 2016 & 2017 & 2018 & 2019 & 2020 \\
\hline Belarus & 11 & 15 & 19 & 26 & 30 & 33 & 38 & 41 & 46 & 51 & 55 & 56 & 55 & 56 & 54 & 55 & 56 \\
\hline Czech & 32 & 35 & 38 & 38 & 38 & 40 & 42 & 44 & 46 & 49 & 50 & 51 & 53 & 56 & 57 & 58 & 57 \\
\hline Hungary & 39 & 41 & 45 & 50 & 54 & 56 & 57 & 58 & 56 & 57 & 58 & 57 & 59 & 61 & 61 & 61 & 60 \\
\hline Kazakhstan & 10 & 15 & 20 & 37 & 52 & 57 & 61 & 65 & 69 & 71 & 72 & 71 & 74 & 75 & 84 & 86 & 96 \\
\hline Kyrgyzstan & 1 & 1 & 1 & 2 & 5 & 8 & 7 & 12 & 16 & 21 & 25 & 30 & 31 & 34 & 37 & 39 & 42 \\
\hline Romania & 18 & 24 & 34 & 42 & 53 & 57 & 59 & 65 & 65 & 64 & 65 & 69 & 67 & 67 & 65 & 64 & 63 \\
\hline Russia & 16 & 23 & 32 & 45 & 62 & 72 & 96 & 117 & 142 & 157 & 185 & 173 & 169 & 164 & 161 & 165 & 165 \\
\hline Serbia & 14 & 14 & 22 & 34 & 41 & 45 & 47 & 47 & 47 & 45 & 44 & 45 & 50 & 45 & 48 & 50 & 50 \\
\hline Ukraine & 20 & 28 & 37 & 52 & 70 & 73 & 77 & 84 & 93 & 104 & 95 & 87 & 89 & 98 & 97 & 96 & 94 \\
\hline
\end{tabular}


Table 3. Commercial bank branches (per 100,000 adults)

Source: Compiled by the authors based on data from the World Bank (2020).

\begin{tabular}{|c|c|c|c|c|c|c|c|c|c|c|c|c|c|c|c|c|c|}
\hline-1 & 004 & 2005 & 2006 & 2007 & 2008 & 2009 & 2010 & 2011 & 2012 & 2013 & 2014 & 2015 & 2016 & 2017 & 2018 & 2019 & 2020 \\
\hline (2) & 22.3 & 32.1 & 4 & 40.7 & 45.5 & 43.9 & 41.2 & 39.8 & 37.5 & 33.7 & 30.4 & 29.5 & 29.4 & 27.9 & 27.5 & 27.6 & 6 \\
\hline & & .7 & 00.9 & 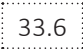 & 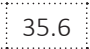 & r.o. & - & 8 & 3 & 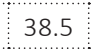 &. & 2. & 0.1 & 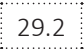 & 3 & 6 & 6 \\
\hline $\mathrm{HL}$ & 3.8 & 8 & 2 & 17.3 & 18.0 & 17.7 & 8 & 4 & 1 & 4 & 5 & 1 & .7 & 6 & 2 & 4 & .4 \\
\hline Ro & 7 & 36.7 & 36.7 & 36.7 & 7 & 5.2 & .4 & 35.3 & 2 & 6 & 30.7 & 8.7 & 8.0 & 6.7 & 5.6 & 23.7 & 2.6 \\
\hline Czech & .0 & 21.4 & 21.9 & 21.6 & 22.8 & 22.7 & 22.6 & 23.3 & 23.8 & 24.3 & 24.2 & 23.7 & 22.4 & 21.3 & 21.3 & 20.6 & 18.3 \\
\hline & & 5.3 & 5 & 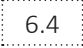 & e & 60 & 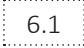 & 72 & 77 & 7.9 & 7.9 & 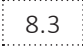 & 8 & 8.2 & 8.1 & 8.0 & 7.6 \\
\hline Kazal & 3.7 & 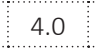 & 3.1 & 3.3 & 3.5 & 3.4 & 3.3 & 3.3 & 3.3 & 3 & 4 & 3.0 & 0 & .8 & .5 & .5 & .4 \\
\hline & & 5.8 & 5.6 & 4.9 & & 3.7 & 3.2 & 2.1 & 1.7 & 6 & 2 & 0.9 & 0.9 & 8 & 8 & 8 & .8 \\
\hline Ukraine & 3.7 & 3.9 & .9 & .9 & 7 & 3.2 & 2.3 & 1.6 & 1.1 & 0.9 & 0.8 & 0.6 & 0.5 & 0.5 & 0.4 & 0.4 & 0.4 \\
\hline
\end{tabular}

2004 provided active policy on digitalization of financial transactions. If we take Kazakhstan, then this country showed average indicators for an increase in the number of ATMs per 100 thousand adults. The lowest rates in terms of the number of ATMs were shown by Kyrgyzstan, Serbia, and Belarus. The reason for this may be the choice of the country in favor of alternative methods of transfers, and in Belarus, this process began in 2019. The trigger for this trend was the crisis - the COVID-19 pandemic.

Further, it is suggested to consider the level of development of commercial banks in the above countries (Table 3).

According to the provided data for 2004, the largest quantity of ATMs was recorded in Romania, Russia, and Serbia. For the same period, low indicators for the number of ATMs were in Kazakhstan (3.7), Ukraine (3.7), and Kyrgyzstan (5.1). In 2009, after the crisis, many countries started closing bank branches. Serbia (43.9), Romania (36.2), and Russia (34.6) had the largest number of bank branches at that time. Ukraine, Kazakhstan, and Belarus, on the contrary, had the smallest numbers (3.2, 3.4, and 3.7, respectively). In 2020, Serbia (27.6), Russia (24.6), and Hungary (23.4) had the largest number of operating bank branches, while Ukraine, Belarus, and Kazakhstan had the least (0.4, 0.8, and 2.4, respectively). This shows that these countries have started to develop actively banking technologies.

In Kazakhstan, from 2005, the number of banks started to increase. This was done to support state programs directed at increasing the availability of lending to small and medium-sized businesses. In
2009 in Kazakhstan, the number of banks started decreasing. This tendency was due to the digitalization of the banking sector and the active development of online banking and mobile banking.

Throughout the period, bank branches were just opening, since access to money had to be provided to the maximum number of residents in the country. However, the mortgage crisis in 2008 showed that many banks in the country do not always favor economic growth. The financial crisis in that period led to the emerging of a new term- financial technologies and starting from 2008 there can be observed bank branches closing.

The COVID-19 pandemic accelerated bank closures because quarantine was introduced and many people did not have access to bank branches. Interestingly, for the shortest period, the greatest part of the population worldwide learned how to use financial technologies such as online banking and mobile payments, and switched to electronic money. The dynamics of cash for the considered period are presented in Figure 1.

Figure 1 shows that governments of many countries have issued many cash resources in 2009, the next year after the financial crisis in 2008. Further, the same development was observed in 2020, after the COVID-19 pandemic. An increase in the amount of Broad Money proves that in the given situation the governments of the countries are pressing to neutralize the consequences of crises and recover those sectors of the economy that have suffered. The components such as the number of mobile phone users and inflation were examined, and it was decided to check whether there is an inverse relationship between the determinants. 


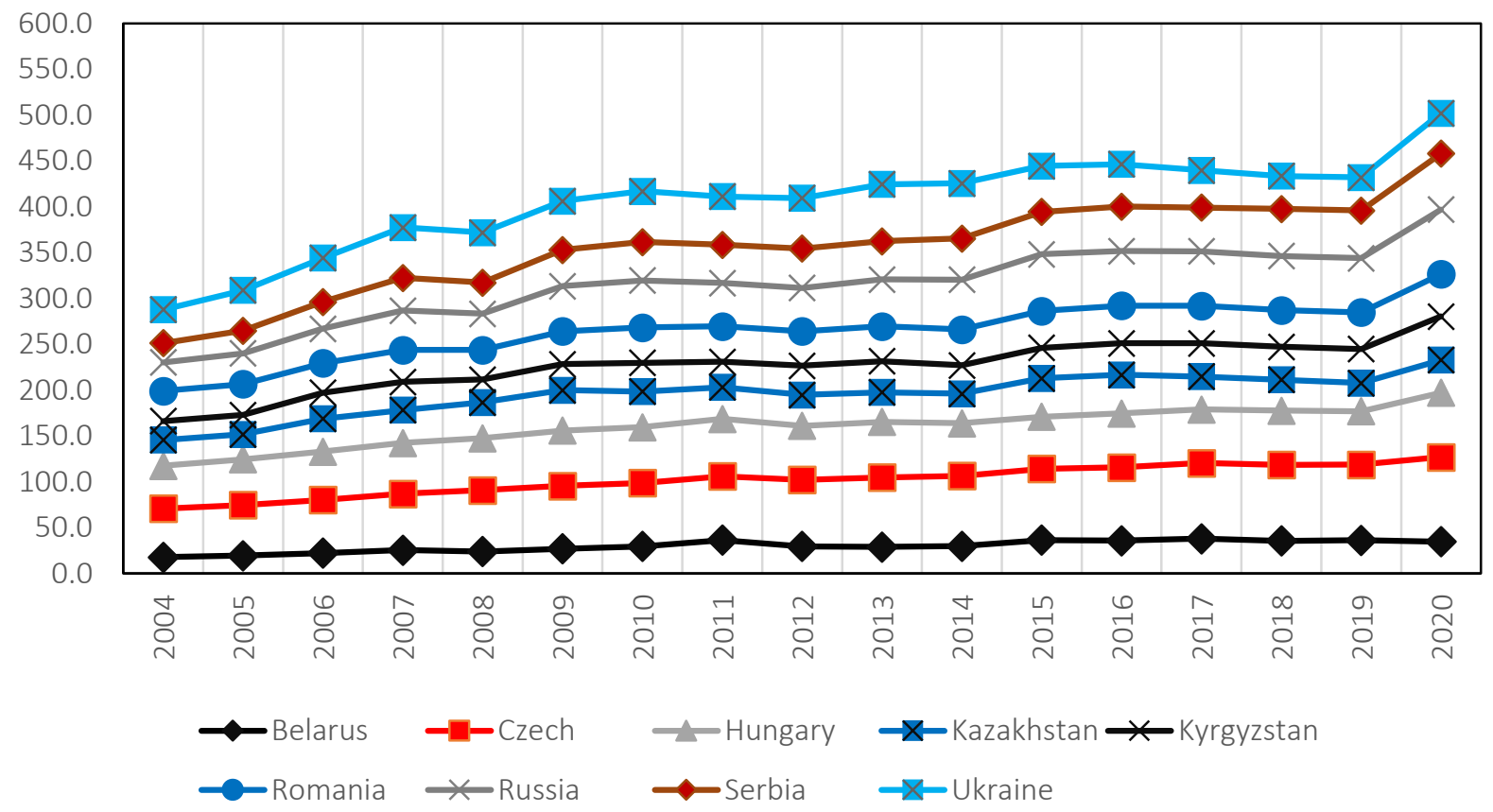

Figure 1. Dynamics of Broad Money (\% of GDP)

\section{RESULTS \\ AND CORRELATION}

The data on selected countries were checked for normal distribution. In this study, to check whether the obtained data satisfy the normal distribution, graphs were constructed P-Plots diagrams. To provide such a procedure, descriptive statis- tics were applied, namely the graphical method through the construction of diagrams. The graphs showed the relationship between the cumulative distribution of samples and the probability distribution of the normal distribution.

Interpretation of plotted graphs: the table shows the quantiles of five distributions:
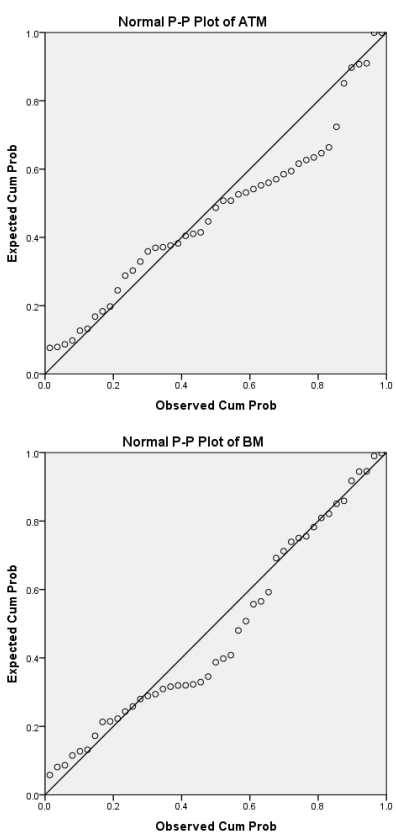
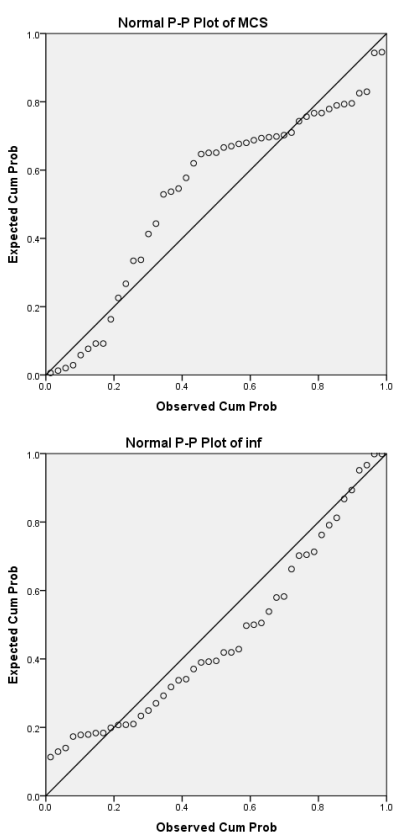

Source: Compiled by the authors.

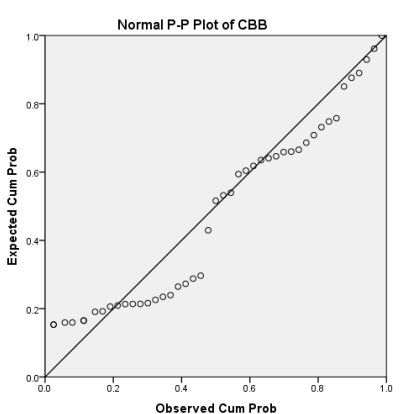

Figure 2. Normal distribution P-Plots diagrams 
a) automated teller machines (ATMs) (per 100,000 adults);

b) mobile cellular subscriptions (per 100 people);

c) commercial bank branches (per 100,000 adults);

d) Broad Money (\% of GDP);

e) Inflation, consumer prices (annual \%).

All distributions were presented as an ascending straight line at an angle of 45 degrees from the lower-left corner of the graph. At a normal distribution, the quantiles of the studied populations should line up in a straight line. These are the theoretically expected normal distribution quantiles.

Then, 45 observations were conducted on every variable, which is less than 50. Therefore, for calculations of the correlation, Spearman's coefficient was provided. All coefficients were calculated using the SPSS software for each year separately, and then summarized in a single Table 4; the coefficients of significance are presented in Appendix A.

Table 4 shows that the relationship between the elements in the matrix changes depending on the period. The strongest positive correlation is between the number of ATMs and mobile cellular subscribers. This relationship does not change throughout the regarded entire period. Only in 2019 and 2020, this relationship is reduced and becomes zero. This indicator is also associated with the Broad Money supply, Broad Money (\% of GDP), which in 2004 was an indicator close to 1.

Regarding the relationship between users of Mobile cellular subscriptions (per 100 people) and Automated teller machines (ATMs), a strong relationship was since early 2004 and declined in 2019-2020. The number of mobile phone users also had a positive correlation with the number of bank branches in studied countries in 2008. During the rest of the time, no strong relationship was marked. The relationship between mobile phone users and the Broad Money supply is similar: a strong rela-

Table 4. Results according to Spearman's rho

\begin{tabular}{|c|c|c|c|c|c|c|}
\hline Year & Indicator & ATM & MCS & CBB & BM & Inf \\
\hline 2004 & \multirow{5}{*}{ ATM } & 1.000 & $.817^{* *}$ & -.017 & $.900 * *$ & -.200 \\
\hline 2007 & & 1.000 & .633 & .017 & $.717^{*}$ & .083 \\
\hline 2008 & & 1.000 & .500 & .017 & .533 & -.033 \\
\hline 2019 & & 1.000 & .350 & -.067 & .017 & $.683^{*}$ \\
\hline 2020 & & 1.000 & .383 & -.050 & -.017 & .100 \\
\hline 2004 & \multirow{5}{*}{ MCS } & $.817^{* *}$ & 1.000 & .233 & $.700^{*}$ & -.167 \\
\hline 2007 & & .633 & 1.000 & .383 & $.800 * *$ & -.300 \\
\hline 2008 & & .500 & 1.000 & .567 & $.717^{*}$ & -.533 \\
\hline 2019 & & .350 & 1.000 & -.300 & -.300 & .300 \\
\hline 2020 & & .383 & 1.000 & -.317 & -.167 & .633 \\
\hline 2004 & \multirow{5}{*}{$\mathrm{CBB}$} & -.017 & .233 & 1.000 & -.283 & $.667^{*}$ \\
\hline 2007 & & .017 & .383 & 1.000 & .017 & $-.750 *$ \\
\hline 2008 & & .017 & .567 & 1.000 & .017 & -.633 \\
\hline 2019 & & -.067 & -.300 & 1.000 & $.683^{*}$ & -.583 \\
\hline 2020 & & -.050 & -.317 & 1.000 & $.700 *$ & -.417 \\
\hline 2004 & \multirow{5}{*}{ BM } & $.900 * *$ & $.700^{*}$ & -.283 & 1.000 & -.483 \\
\hline 2007 & & $.717^{*}$ & $.800 * *$ & .017 & 1.000 & -.133 \\
\hline 2008 & & .533 & $.717^{*}$ & .017 & 1.000 & -.400 \\
\hline 2019 & & .017 & -.300 & $.683^{*}$ & 1.000 & -.517 \\
\hline 2020 & & -.017 & -.167 & $.700^{*}$ & 1.000 & -.300 \\
\hline 2004 & \multirow{5}{*}{$\operatorname{lnf}$} & -.300 & -.167 & $.667 *$ & -.483 & 1.000 \\
\hline 2007 & & .083 & -300 & $-.750 *$ & -.133 & 1.000 \\
\hline 2008 & & -.300 & -.167 & .200 & -.483 & 1.000 \\
\hline 2019 & & $.683^{*}$ & .300 & -.583 & -.517 & 1.000 \\
\hline 2020 & & .100 & .633 & -.417 & -.300 & 1.000 \\
\hline
\end{tabular}

Note: ${ }^{*}$ Correlation is significant at the 0.01 level (2-tailed); * correlation is significant at the 0.05 level (2-tailed). 
tionship between determinants in 2004, 2007, and 2008. In the last two years, this connection has been destroyed. At the same time, a relationship appeared between inflation (only in 2019).

Commercial bank branches: this indicator correlated mobile phone users only in 2007. In 20192020 , there was a strong relationship with Broad Money $\left(0.683^{\star}\right.$ and $0.700^{\star}$ - both significant ratios).

Correlation between Broad Money and ATMs, and between users of mobile payments: a strong relationship was followed in the early years. In 2004, 2007 and 2008, the correlation coefficients were strong, positive, and significant. In 2019-2020, the relationship was completely lost. If we consider the interdependence between bank branches and Broad Money supply, it appeared in 2019-2020. A stronger correlation between Broad Money supply and inflation was in 2019

The last indicator in the matrix is inflation - interdependencies are not constant, sometimes positive (for example, with ATMs in 2019 or between mobile phone users in 2020), sometimes negative (for example, MCS in 2008, CBB in 2008 and 2019, and BM in 2019). Thus, for 2020, the statistically largest correlation is observed between Broad Money supply and commercial bank branches.

Broad Money: in other words, cash in circulation or in the savings of the population. In the beginning, the appearance of such money was associated with ATMs: plastic card owners withdrew money from accounts through terminals. Then this need disappeared for the above-mentioned reason - the development of Fintech and the spread of the COVID-19 pandemic. Many scientists have shown in their works the relationship between money supply and economic crises in the United States, and not only (Benati, 2009).
Inflation is quite a sensitive indicator, since earlier there was no relationship with this economic indicator, but it appeared exactly in the last studied years. This can be explained by the impact of the crisis triggered by the COVID-19 pandemic. Production stopping for some period led to the fact that the business at first for the first year in 2019 survived at the expense of stocks, which soon ran out and it was time to save. Such conditions developed massive shortages in many areas, which affected the rise in prices, especially for mobile phones, as the most massive technical means of communication. Inflation complicates the process of decision-making by banks regarding interest rates. As a result, the volume of business lending is limited, and the development of the economy slows down. However, some scientists believe that inflation can postpone production and accelerate the way out of the current crisis (Ebrill \& Fries, 1991).

Based on this study, it can be concluded that the null hypothesis is confirmed for the period 20192020. At the same time, at least one of the tests for the period 2004-2009 could not reject the alternative hypothesis. The results of the study demonstrate that studied indicators had a different level of correlation, which was stable before the pandemic but changed both upward and downward.

Based on the results of the study, it is possible to draw conclusions on the following hypotheses:

H0: The correlation coefficient is zero, i.e., there is no relationship between ATMs and independent indicators - rejected.

H1: The correlation coefficient is not zero, i.e., there is a relationship between ATMs and independent indicators - accepted and confirmed.

\section{CONCLUSION}

The study's aim was to evaluate correlations between determinants of non-cash payments and various economic indicators (broad money, inflation, consumer prices) and identify which of the factors and to what extent influence each other in different periods. The analysis of the banking sector was provided. For this purpose, the correlation between the elements was calculated through the provision of correlation analysis (Spearman's coefficient), which considered 2004, 2008, 2009, 2019, and 2020. Data for nine countries were used for analysis: Kazakhstan, Kyrgyzstan, Ukraine, Belarus, Russia, the Czech Republic, 
Hungary, Romania, and Serbia. To sum up, the alternative hypothesis that the existing relationships are significant is considered to be confirmed for the period 2004-2009. At the same time, in the presented study of the significance level for the period 2019-2020, the null hypothesis was confirmed.

Earlier studies had some contradictions that were explored in this study, and the following conclusion can be drawn. The study showed that in countries under consideration the main indicator, ATM, has significantly changed relationships between the indicators. The base year was adopted in 2004 and the most significant relationships between ATM and MCS, ATM and BM were traced exactly in this year $\left(, 817^{\star *}\right.$ and, $\left.900^{* *}\right)$. In the following crises, the correlations weakened and lost their significance. Regarding the correlation between indicators, a sharp change was marked in the next year after the crises, and it was in 2009 and 2020 because of two past financial crises: the financial and economic crisis of 2008 and the COVID-19 pandemic.

According to ATMs, noncash payments are currently moving to a new level. In the early days, ATMs were associated with innovation and became more widespread. Recently, this technology has reached a new level of its development. ATMs lag mobile applications, and to catch up with the present, new functions are now being created, which were not even mentioned before.

Branches of commercial banks were necessary for money transfers earlier. Before COVID-19 in 20072008, in the considered countries they increased the distribution of payment plastic cards: debit and credit. This was the reason for a positive relationship between the owners of mobile phones and branches. In recent years, there was no such a relationship, which can be explained, first of all, by a satiated market: in developing countries, more than $80 \%$ of adults over the age of 16 have plastic cards. Secondly, since 2019, mobile applications (ApplePay, SumsungPay, etc.) have been developing very actively, and the population could bind one plastic card to several payment systems, which can also be opened online. There is no need in coming to bank departments.

Thus, this study showed that modern developments differ from those presented earlier, and financial transformation of financial technologies is still in the process. The results of the study also show that further studies on non-traditional measures of financial development that can lead to stable economic growth during the post-crisis period are necessary. Thus, future scientists are encouraged to repeat this study using a large sample to obtain the best results of correlation analysis. It would also be interesting to assess the degree of impact of the COVID-19 pandemic on cashless payments and financial and economic indicators in other countries.

\section{LIMITATIONS}

The main limitation of this study was limited data on the considered indicators in all countries of Central Asia. This is due to the fact that in Kazakhstan data has been collected for a long time and such reports were submitted to the Central Bank. The rest of the region has begun to actively collect data on financial technology in recent years.

\section{AUTHOR CONTRIBUTIONS}

Conceptualization: Anna Kredina, Saule Nurymova, Azimkhan Satybaldin, Anel Kireyeva.

Data curation: Saule Nurymova.

Formal analysis: Azimkhan Satybaldin.

Funding acquisition: Azimkhan Satybaldin.

Investigation: Anna Kredina, Anel Kireyeva.

Methodology: Anna Kredina.

Project administration: Saule Nurymova. 
Resources: Saule Nurymova.

Software: Anna Kredina, Anel Kireyeva.

Supervision: Anna Kredina, Azimkhan Satybaldin.

Writing - original draft: Anna Kredina, Anel Kireyeva.

\section{ACKNOWLEDGMENTS}

The study was carried out within the framework of program targeted IRN OR11465433 funding by the Science Committee of the Ministry of Education and Science of the Republic of Kazakhstan "Development of the concept and mechanisms of balanced territorial development of the economy and society of Kazakhstan".

\section{REFERENCES}

1. Afaha, J. S. (2019). Electronic Payment Systems (E-payments) and Nigeria Economic Growth. European Business \& Management, 5(6), 77. https://doi.org/10.11648/J. EBM.20190506.11

2. Alamoudi, H. (2022). Examining Retailing Sustainability in the QR Code-Enabled Mobile Payments Context During the COVID-19 Pandemic. International Journal of Customer Relationship Marketing and Management (IJCRMM), 13(1), 1-22. https://doi. org/10.4018/ijcrmm.289210

3. Al-Hawari, M., Hartley, N. \& Ward, T. (2005). Measuring banks' automated service quality: a confirmatory factor analysis approach. Marketing Bulletin, 16(1), 1-19. Retrieved from http://marketing-bulletin.massey.ac.nz/V16/ MB_V16_A1_AlHawari.pdf

4. Aysan, A. F., \& Ceyhan, Ş. P. (2008). What determines the banking sector performance in globalized financial markets? The case of Turkey. Physica A: Statistical Mechanics and its Applications, 387(7), 15931602. https://doi.org/10.1016/J. PHYSA.2007.11.003

5. Ball, L., \& Sheridan, N., (2004). Does inflation targeting matter? In B.S. Bernanke, \& M. Woodford (Eds.), The Inflation-Targeting Debate (pp. 249-276). University of Chicago Press. Retrieved from https://www.nber.org/booksand-chapters/inflation-targetingdebate/does-inflation-targetingmatter
6. Banerjee, R. N., Mehrotra, A., \& Zampolli, F. (2020). Inflation at risk from Covid-19. BIS Bulletin, 28. Bank for International Settlements. Retrieved from https:// www.bis.org/publ/bisbull28.pdf

7. Benati, L. (2009). Long-Run Evidence on Money Growth and Inflation (ECB Working Paper No. 1027). Monetary Economics. http://dx.doi.org/10.2139/ ssrn. 1345758

8. Casado-Aranda, L. A., LiébanaCabanillas, F., \& SánchezFernández, J. (2018). A neuropsychological study on how consumers process risky and secure E-payments. Journal of Interactive Marketing, 43, 151-164. https://doi.org/10.1016/J.INTMAR.2018.03.001

9. Chen, L. D., \& Nath, R. (2008). Determinants of mobile payments: an empirical analysis. Journal of International Technology and Information Management, 17(1), 9-20. Retrieved from https://scholarworks.lib.csusb.edu/jitim/vol17/ iss $1 / 2$

10. Cobham, D., \& Kang, Y. (2012). Financial crisis and quantitative easing: can Broad Money tell us anything? The Manchester School, 80(1), 54-76. https://doi.org/10.1111/j.14679957.2012.02323.x

11. Dahlberg, T., Mallat, N., Ondrus, J., \& Zmijewska, A. (2008). Past, present and future of mobile payments research: A literature review. Electronic Commerce
Research and Applications, 7(2), 165-181. https://doi.org/10.1016/j. elerap.2007.02.001

12. De, R., Pandey, N., \& Pal, A. (2020). Impact of digital surge during Covid-19 pandemic: A viewpoint on research and practice. International Journal of Information Management, 55, 102171. https://doi.org/10.1016/j. ijinfomgt.2020.102171

13. Ebrill, L. P., \& Fries, S. M. (1991). Broad Money growth and inflation in the United States. Staff Papers, 38(4), 736-750. Retrieved from https://www.elibrary.imf. org/view/journals/024/1991/003/ article-A003-en.xml

14. Gawer, A. (2014). Bridging Differing Perspectives on Technological Platforms: Toward an Integrative Framework. Research Policy, 43(7), 12391249. https://doi.org/10.1016/J. RESPOL.2014.03.006

15. Gonçalves, C. E. S., \& Salles, J. M. (2008). Inflation targeting in emerging economies: What do the data say? Journal of Development Economics, 85(1-2), 312-318. https://doi.org/10.1016/j.jdeveco.2006.07.002

16. Islam, R., Kumar, S., \& Biswas, P. K. (2007). Customer satisfaction of ATM service: a case study of HSBC ATM. Dhaka University Journal of Marketing, Forthcoming. Retrieved from https://ssrn.com/ abstract $=990242$

17. Joseph, M. \& Stone, G. (2003). An empirical evaluation of US 
bank customer perceptions of the impact of technology on service delivery in the banking sector. International Journal of Retail \& Distribution Management, 31(4), 190-202. https://doi. org/10.1108/09590550310469185

18. Kaur, P., Krishan, K., Sharma, S. K., \& Kanchan, T. (2019). ATM card cloning and ethical considerations. Science and Engineering Ethics, 25(5), 1311-1320. https://doi. org/10.1007/s11948-018-0049-X

19. Kumbhar, V. (2011). Factors affecting on customers' satisfaction: an empirical investigation of ATM service. International Journal of Business Economics and Management Research, 2(3), 144156. Retrieved from https://mpra. ub.uni-muenchen.de/32713/

20. Kumbirai, M., \& Webb, R. (2010). A financial ratio analysis of commercial bank performance in South Africa. African Review of Economics and Finance, 2(1), 30-53. https://doi.org/10520/ EJC124697

21. Luca, A.D., Langheinrich, M., \& Hußmann, H. (2010). Towards understanding ATM security: a field study of real world ATM use. In Proceedings of the sixth symposium on usable privacy and security. https://doi. org/10.1145/1837110.1837131

22. Mahran, A.F., \& Enaba, H.M. (2011). Exploring Determinants Influencing the Intention to Use Mobile Payment Service. International Journal of Customer Relationship Marketing and Management, 2(4), 17-37. https://doi. org/10.4018/JCRMM.2011100102

23. Nettleton, D. (2014). Selection of Variables and Factor Derivation. Commercial Data Mining, 79-104. https://doi.org/10.1016/ B978-0-12-416602-8.00006-6

24. Oliveira, T. P., Moral, R. A., Zocchi, S. S., Demétrio, C. G., \& Hinde, J. (2020). lcc: an R package to estimate the concordance correlation, Pearson correlation and accuracy over time. PeerJ, 8, e9850. https://doi.org/10.7717/peerj.9850

25. Raja, J., Velmurgan, M., \& Seetharaman, A. (1970). E-payments:
Problems and Prospects. The Journal of Internet Banking and Commerce, 13(1), 1-17. Retrieved from https://www.icommercecentral.com/open-access/epayments-problems-and-prospects. php?aid=38419

26. Ren, T., \& Tang, Y. (2020). Accelerate the promotion of mobile payments during the COVID-19 epidemic. The Innovation, 1(2), 100039. https://doi.org/10.1016/j. xinn.2020.100039

27. Riedl, P., Mayrhofer, R., Möller, A., Kranz, M., Lettner, F., Holzmann, C., \& Koelle, M. (2015). Only play in your comfort zone: interaction methods for improving security awareness on mobile devices. Personal and Ubiquitous Computing, 19, 941-954. https://doi. org/10.1007/s00779-015-0840-5

28. Shkolnyk, I., Kozmenko, S., Kozmenko, O., \& Mershchii, B. (2019). The Impact of the Economy Financialization on the Level of Economic Development of the Associate EU Member States. Economics \& Sociology, 12(4), 43-58. https://doi.org/10.14254/2071789X.2019/12-4/2

29. Shvets, S. (2020). The golden rule of public finance under active monetary stance: endogenous setting for a developing economy. Investment Management and Financial Innovations, 17(2), 216230. http://dx.doi.org/10.21511/ imfi.17(2).2020.17

30. Sobolev, E. V. (2021). The Transformation of Economic Crises: Meaningful Constancy in Changing Forms. Entrepreneur's Guide, 14(2), 78-85. (In Russian). https:// doi.org/10.24182/2073-98852021-14-2-78-85

31. Soldatenko, T., \& Essimzhanova, S. (2021). E-commerce Jump 2020, the Survey of Suppliers and Consumers in Kazakhstan, as well as Ways for Growth Following Worldwide Leaders Examples. Eurasian Journal of Economic and Business Studies, 3(61). https://doi. org/10.47703/ejebs.v3i61.59

32. Spokeviciute, L., Keasey, K., \& Vallascas, F. (2019). Do financial crises cleanse the banking industry? Evidence from US commercial bank exits. Journal of Banking \& Finance, 99, 222-236. https://doi.org/10.1016/J.JBANKFIN.2018.12.010

33. Sreelakshmi, C. C., \& Prathap, S. K. (2020). Continuance adoption of mobile-based payments in Covid-19 context: an integrated framework of health belief model and expectation confirmation model. International Journal of Pervasive Computing and Communications, 16(4), 351-369. https://doi. org/10.1108/ijpcc-06-2020-0069

34. World Bank. (2020). Annual statistical collections of the World bank. Retrieved from https://data. worldbank.org/indicator

35. World Health Organization (WHO). (2020). WHO Coronavirus (COVID-19) Dashboard. https://doi.org/10.46945/ bpj.10.1.03.01

36. Yu, H., Wei, E., \& Berry, R.A. (2019). A Business Model Analysis of Mobile Data Rewards. IEEE INFOCOM 2019 - IEEE Conference on Computer Communications (pp. 2098-2106). https://doi.org/10.1109/INFOCOM.2019.8737504 


\section{APPENDIX A}

Table A1. Significance coefficients (2-tailed)

Source: Compiled by the authors.

\begin{tabular}{|c|c|c|c|c|c|c|}
\hline Year & Indicator & ATM & MCS & CBB & BM & Inf \\
\hline 2004 & \multirow{5}{*}{ ATM } & - & .007 & .966 & .001 & .606 \\
\hline 2007 & & - & .067 & .966 & .030 & .831 \\
\hline 2008 & & - & .170 & .966 & .139 & .932 \\
\hline 2019 & & - & .356 & .865 & .966 & .042 \\
\hline 2020 & & - & .308 & .898 & .966 & .798 \\
\hline 2004 & \multirow{5}{*}{ MCS } & .007 & - & .546 & .036 & .668 \\
\hline 2007 & & .067 & - & .308 & .010 & .433 \\
\hline 2008 & & .170 & - & .112 & .030 & .139 \\
\hline 2019 & & .356 & - & .433 & .433 & .433 \\
\hline 2020 & & .308 & - & .406 & .668 & .067 \\
\hline 2004 & \multirow{5}{*}{$\mathrm{CBB}$} & .966 & .546 & - & .460 & .050 \\
\hline 2007 & & .966 & .308 & - & .433 & .020 \\
\hline 2008 & & .966 & .112 & - & .966 & .067 \\
\hline 2019 & & .865 & .433 & - & .042 & .099 \\
\hline 2020 & & .898 & .406 & - & .036 & .265 \\
\hline 2004 & \multirow{5}{*}{$\mathrm{BM}$} & .001 & .036 & .460 & - & .187 \\
\hline 2007 & & .030 & .010 & .966 & - & .732 \\
\hline 2008 & & .139 & .030 & .966 & - & .286 \\
\hline 2019 & & .966 & .433 & .042 & - & .154 \\
\hline 2020 & & .966 & .668 & .036 & - & .433 \\
\hline 2004 & \multirow{5}{*}{$\operatorname{lnf}$} & .433 & .668 & .050 & .187 & - \\
\hline 2007 & & .831 & .433 & .020 & .732 & - \\
\hline 2008 & & .433 & .668 & .606 & .187 & - \\
\hline 2019 & & .042 & .433 & .099 & .154 & - \\
\hline 2020 & & .798 & .067 & .265 & .433 & - \\
\hline
\end{tabular}

